\title{
Collision-Activated Dissociation, Infrared Multiphoton Dissociation, and Electron Capture Dissociation of the Bacillus anthracis Siderophore Petrobactin and Its Metal Ion Complexes
}

\author{
Haichuan Liu and Kristina Håkansson \\ Department of Chemistry, University of Michigan, Ann Arbor, Michigan, USA \\ Jung Yeop Lee and David H. Sherman \\ Life Sciences Institute and Department of Medicinal Chemistry, University of Michigan, Ann Arbor, \\ Michigan, USA
}

Siderophores are high-affinity iron-chelating ligands produced by microorganisms to scavenge vital $\mathrm{Fe}^{3+}$ from the environment. Thus, siderophores constitute potential therapeutic targets and their structural determination is important for exploiting their therapeutic value. Here, the virulence-associated siderophore petrobactin from Bacillus anthracis was characterized with electron capture dissociation (ECD). Fragmentation of doubly protonated petrobactin was investigated and compared to sustained off-resonance irradiation collision-activated dissociation (SORI CAD) and infrared multiphoton dissociation (IRMPD) of both the singly and doubly protonated species. These experiments demonstrate that ECD provides additional information (complementary bond cleavages) on the structure of petrobactin compared to both SORI CAD and IRMPD. Furthermore, complexes of petrobactin with divalent $\left(\mathrm{Ca}^{2+}, \mathrm{Fe}^{2+}\right.$, and $\left.\mathrm{Co}^{2+}\right)$ and trivalent $\left(\mathrm{Fe}^{3+}\right.$ and $\left.\mathrm{Ga}^{3+}\right)$ metal cations were also subjected to SORI CAD and ECD. Again, most structural information was obtained from the ECD spectra. However, significant differences were found in both SORI CAD and ECD of metal complexes, dependent on the nature of the metal ion. Intriguingly, unique behavior, consistent with a recently proposed solution-phase structure, was observed for the highly preferred $\mathrm{Fe}^{3+}$-petrobactin complex. (J Am Soc Mass Spectrom 2007, 18, 842-849) (C) 2007 American Society for Mass Spectrometry

$O^{i}$ iderophores are low molecular weight, highaffinity iron-chelating agents produced by bacteria, fungi, and marine organisms to solubilize and scavenge $\mathrm{Fe}^{3+}$ from the environment [1-4]. A wide structural versatility has been found in the more than 200 siderophores reported so far [4]. These molecules can be classified into two main types with respect to their iron-binding groups: catecholate and hydroxamate. For example, petrobactin biosynthesized by both the marine bacterium Marinobacter hydrocarbonoclasticus [5] and by Bacillus anthracis [6, 7] is a catecholate-type siderophore, whereas most siderophores (such as fusarinines, corogens, and ferrichromes) produced by fungi belong to the hydroxamate family [4].

Structural determination of siderophores is essential

Published online February 28, 2007

Address reprint requests to Dr. Kristina Hakansson, University of Michigan, Department of Chemistry, 930 N. University, Ann Arbor, MI 481091055, USA. E-mail: kicki@umich.edu for understanding their $\mathrm{Fe}^{3+}$ chelation properties. Electrospray ionization mass spectrometry (ESI MS) and tandem mass spectrometry (MS/MS) have proved to be powerful techniques for detecting and identifying siderophores [5-23]. For example, Gledhill demonstrated the utility of these techniques for characterizing hydroxamate-type siderophores, including ferrioxamine, ferrichrome, and iron(III) rhodotoluate [9]. The same research group also showed that coupling of high-performance liquid chromatography (HPLC) with ESI MS is an effective strategy for separation and identification of siderophores in complex samples [19]. Gibson and coworkers applied MS/MS to characterize exochelin siderophores and found that its side chains are both saturated and unsaturated and terminated with either a caboxylate group or a methyl ester [11,21]. These results contrasted with the previous observation that exochelins are unsaturated and terminated with carboxylic acid [16]. Butler and coworkers used ESI MS and MS/MS for structural characterization of several 
siderophores produced by marine bacteria $[5,8,17,18]$. MS and MS/MS techniques have also been applied to siderophores complexed with metal ions. For example, Groenewold et al. [12] investigated the fragmentation of desferrioxamine siderophore complexed with $\mathrm{UO}_{2}^{2+}, \mathrm{Fe}^{3+}$, and $\mathrm{Ca}^{2+}$ upon collision-activated dissociation (CAD). It was found that the most abundant CAD product ions were those associated with cleavages of the hydroxamate moieties, which are involved in metal complexation. In other work, complexes of desferriferricrocin siderophore with $\mathrm{Fe}^{3+}, \mathrm{Cr}^{3+}, \mathrm{Al}^{3+}, \mathrm{Ga}^{3+}, \mathrm{Cu}^{2+}$, and $\mathrm{Zn}^{2+}$ were synthesized and characterized with ESI MS and other techniques [22]. Here, the hydroxamate groups and amide nitrogens/carbonyl oxygens were found to be bound to the metal ions.

To our knowledge, CAD is the only MS/MS technique that has been used for structural characterization of siderophores. During the past decade, electron capture dissociation (ECD) [24-26] has emerged as a powerful complementary MS/MS strategy for biomolecular structural determination, particularly for peptide and protein analysis. ECD results in cleavage of peptide backbone $\mathrm{N}-\mathrm{C} \alpha$ bonds, forming $c$ - and $z$-type product ions in contrast to the $b$ - and $y$-type ions resulting from conventional MS/MS techniques (such as CAD). A very attractive feature of ECD is that labile posttranslational modifications (PTMs) preferentially lost on collisional activation can be preserved [27-30], thereby allowing their localization. In addition, this "soft" nature of ECD allows cleavage of protein $\mathrm{N}-\mathrm{C} \alpha$ bonds without disrupting noncovalent interactions, thereby providing higher-order structure information [31-33]. ECD has also been shown to yield complementary structural information compared to CAD for other macromolecules, including polymers [34, 35], oligonucleotides [36-38], and lantibiotics [39]. Here, we present ECD of a $B$. anthracis siderophore, petrobactin, carrying two protons, or a metal cation. ECD fragmentation patterns are also compared to those obtained with sustained off-resonance irradiation (SORI) CAD and infrared multiphoton dissociation (IRMPD).

\section{Experimental}

Sample

Bacillus anthracis strain Sterne $34 \mathrm{~F}_{2}$ was grown in an iron-depleted medium (IDM), prepared as described previously [7, 40], ®o®induceßsiderophore®production. Cells were removed from the culture broths by filtration in $0.20-\mu \mathrm{m}$ filter flasks (Corning Inc., Corning, NY). Supernatants were adjusted to $\mathrm{pH} 7.0$ and subsequently loaded onto a column packed with Amberlite ${ }^{\circledR}$ XAD-16 (Supelco, Bellefonte, PA). After water washing, 100\% methanol was applied for elution of bound material. Highly purified petrobactin was obtained by preparative high-performance liquid chromatography (HPLC) with a $\mathrm{C}_{18}$ reverse-phase semi-prep column (Symmetry Prep $\mathrm{C}_{18}, 7 \mu \mathrm{m}, 7.8 \times 300 \mathrm{~mm}$, Waters, Milford, MA).
HPLC separation was performed on a Beckman Coulter system (Fullerton, CA) with a diode-array detector using a linear stepwise gradient from 5 to $50 \%$ aqueous acetonitrile in $0.1 \%$ (vol/vol) trifluoroacetic acid (TFA) at a flow rate of $1.5 \mathrm{~mL} / \mathrm{min}$ over $40 \mathrm{~min}$. HPLC peaks with siderophore activity were collected and lyophilized for mass spectral analysis.

\section{Electrospray Ionization Mass Spectrometry}

Gas-phase protonated and metal-adducted petrobactin (monoisotopic molecular weight $=718.3536 \mathrm{Da}$ ) were generated by ESI at $70 \mu \mathrm{L} / \mathrm{h}$ (Apollo ion source, Bruker Daltonics, Billerica, MA) of a spray solution (1:1 MeOH: $\left.\mathrm{H}_{2} \mathrm{O}\right)$ containing $10 \mu \mathrm{M}$ petrobactin and a mixture of $5 \mu \mathrm{M}$ petrobactin and $20 \mu \mathrm{M} \mathrm{M}_{\mathrm{x}}^{2+}$ or $\mathrm{M}_{\mathrm{y}}^{3+}\left(\mathrm{M}_{\mathrm{x}}^{2+}=\mathrm{Ca}^{2+}\right.$, $\mathrm{Fe}^{2+}$, and $\mathrm{Co}^{2+} ; \mathrm{M}_{\mathrm{y}}^{3+}=\mathrm{Fe}^{3+}$ and $\mathrm{Ga}^{3+}$ ), respectively. Acid was not added for two reasons: first, two additional high-abundance ions, suppressing the signal from petrobactin, appeared when acid was present; and, second, favorable conditions for detection of siderophore-metal complexes were needed. $\mathrm{FeBr}_{2}, \mathrm{CoBr}_{2}$, and $\mathrm{GaCl}_{3}$ were purchased from Aldrich (St. Louis, $\mathrm{MO}$ ), whereas $\mathrm{FeCl}_{3}$ and $\mathrm{CaCl}_{2}$ were purchased from Aldrich (Milwaukee, WI) and Fisher (Fair Lawn, NJ), respectively. All mass spectra were collected with an actively shielded 7-Tesla Fourier transform ion cyclotron resonance (FT-ICR) mass spectrometer with a quadrupole front end (APEX-Q, Bruker Daltonics). Ions produced by ESI were externally accumulated in a hexapole for $2 \mathrm{~s}$, transferred by highvoltage ion optics, and captured in an Infinity ICR cell by gated trapping. This accumulation sequence was looped six times to improve precursor signal-to-noise $(\mathrm{S} / \mathrm{N})$ ratios (high $\mathrm{S} / \mathrm{N}$ ratios are required for $\mathrm{ECD}$ [24]).

\section{Tandem Mass Spectrometry}

In MS/MS experiments, mass selective external accumulation of protonated or metal-adducted petrobactin ions was followed by further isolation by correlated

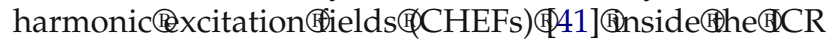
cell. For ECD, low-energy electrons were provided by

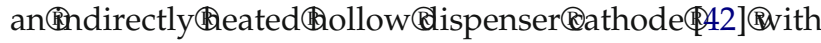
a bias voltage of $-1 \mathrm{~V}$. An electron irradiation time of $300 \mathrm{~ms}$ was used for both protonated and metaladducted petrobactin ions. For SORI CAD, a radio frequency offset by $-1000 \mathrm{~Hz}$ from the precursor ion's cyclotron frequency was applied for 4-16 ms while argon was pulsed into the ICR cell to a pressure reading of about $10^{-7}$ mbar (gauge calibrated for $\mathrm{N}_{2}$ ). For IRMPD, petrobactin ions were irradiated by infrared photons provided by a $\mathrm{CO}_{2}$ laser $(25 \mathrm{~W}, 10.6 \mu \mathrm{m}$; Synrad, Mukilteo, WA). Laser irradiation lasted for 70-120 ms at 40\% laser power. All data were acquired with XMASS software (version 6.1, Bruker Daltonics) in broadband mode from $\mathrm{m} / \mathrm{z}=100$ to 2000 with $256-512 \mathrm{~K}$ data points and summed over 32 or 50 scans. Mass 
spectra were analyzed with the MIDAS analysis soft-

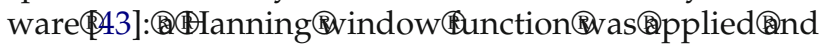
the datasets were zero filled once before fast Fourier transformation and magnitude calculation.

\section{Results and Discussion}

\section{SORI CAD and IRMPD of Protonated Petrobactin}

We previously used SORI CAD to characterize the

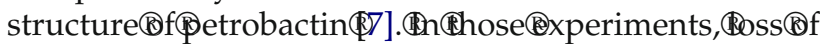
$\mathrm{H}_{2} \mathrm{O}$ was the dominant process for singly protonated petrobactin, whereas two abundant product ions at $\mathrm{m} / \mathrm{z}=137.03$ and 194.08 were observed for [petrobactin + $2 \mathrm{H}]^{2+}$ (the structure of petrobactin and the identity of these product ions are shown in Scheme 1).

For both charge states, two minor product ions at $m / z=282.18$ and 438.19 were also detected. Formation of the product ions at $m / z=137.02,282.18$, and 438.19 is associated with cleavage of three amide $\mathrm{N}-\mathrm{C}(\mathrm{O})$ bonds in petrobactin. However, the product ion at $\mathrm{m} / \mathrm{z}=$ 194.08 is produced through rupture of an amine $\mathrm{N}-\mathrm{C}(\mathrm{C})$ bond. Another minor product ion assigned to [583.35 $\left.-\mathrm{H}_{2} \mathrm{O}\right]^{+}$was observed in SORI CAD of [petrobactin $+\mathrm{H}^{+}$. This product ion is structurally complementary to the one at $\mathrm{m} / \mathrm{z}=137.02$ with the exception of the additional $\mathrm{H}_{2} \mathrm{O}$ loss. No product ions corresponding to $\mathrm{C}-\mathrm{C}$ bond cleavage were observed. These results are consistent with those obtained with a Q-star@uadrupole@ime-of-flight $\$$ nass@pectrometer@6].

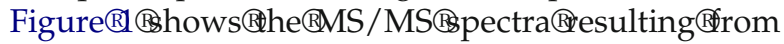
IRMPD of singly and doubly protonated petrobactin.

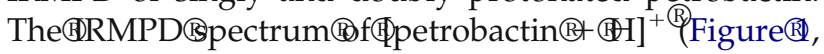
top) is nearly identical to the SORI CAD spectrum of the

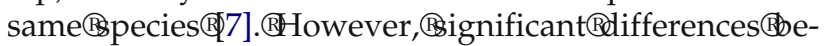
tween IRMPD and SORI CAD were found for doubly protonated petrobactin. First, the product ion at $\mathrm{m} / \mathrm{z}=$

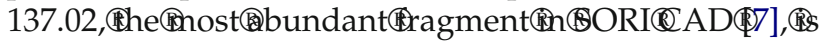
not observed after IRMPD. Second, an additional product ion at $m / z=265.16$ is found in the IRMPD spectrum. This product ion may be a result of direct fragmentation of a $\mathrm{N}-\mathrm{C}(\mathrm{C})$ bond and/or secondary fragmentation involving $\mathrm{NH}_{3}$ loss from the product at $\mathrm{m} / \mathrm{z}=282.18$, consistent with the higher propensity for secondary fragmentation in IRMPD resulting from further activation of products remaining in the laser path. Finally, the relative abundance of the product ions at $\mathrm{m} / \mathrm{z}=282.18$ and 438.19 is significantly higher in IRMPD compared

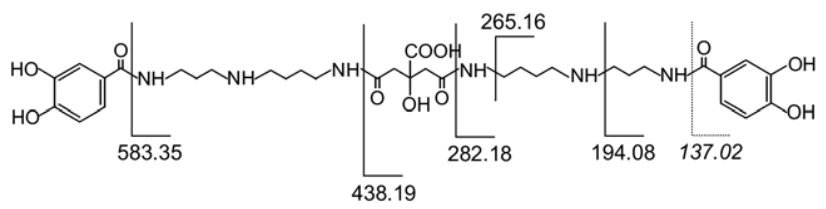

Scheme 1. Structure of petrobactin and summary of observed bond cleavages in IRMPD and SORI CAD of the protonated species. The dotted line represents a cleavage that was observed only in SORI CAD of [petrobactin $+2 \mathrm{H}]^{2+}$.
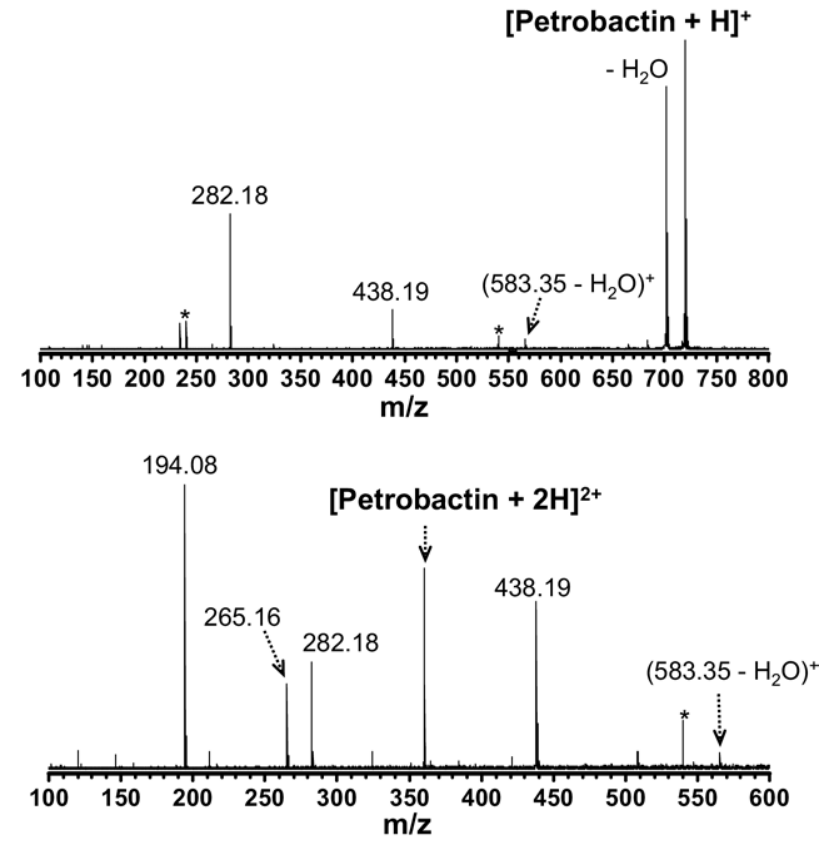

Figure 1. MS/MS spectra resulting from IRMPD (40\% laser power, 16 scans) of [petrobactin $+\mathrm{H}]^{+}$(top, 70-ms irradiation) and [petrobactin $+2 \mathrm{H}]^{2+}$ (bottom, 120-ms irradiation).

to that in SORI CAD. These differences may be related to differences in the amount of secondary fragmentation and the different activation processes involved in CAD versus IRMPD: CAD fragmentation is generally

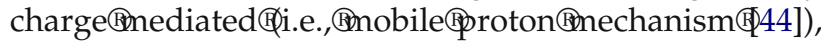
whereas resonance excitation of certain functional groups (such as carbonyls) occurs in IRMPD.

The preferred fragmentation of the central citrate moiety, resulting in $\mathrm{H}_{2} \mathrm{O}$ loss (although this product could also originate from the dihydroxybenzoyl groups), and the product ions at $\mathrm{m} / \mathrm{z}=282.18$ and 438.19 in SORI CAD and IRMPD of singly protonated petrobactin may be explained by the preferred protonation of that functional group. For [petrobactin + $2 \mathrm{H}]^{2+}$, the presence of a second proton can contribute to additional charge-directed fragmentation pathways in SORI CAD, including the abundant cleavage of $\mathrm{N}-\mathrm{C}(\mathrm{O})$ bonds adjacent to the dihydroxybenzoyl moiety (forming the product ion at $m / z=137.02$ ).

\section{ECD of Protonated Petrobactin}

One caveat of ECD can be that precursor ions need to carry at least two charges. However, doubly protonated petrobactin was detected after ESI from the non-metal-containing solvent (data not shown). Thus, such ions could be mass-selectively accumulated and subjected to ECD. The corresponding spectrum is displayed 2) observed after ECD is different from that obtained from either SORI CAD or IRMPD: the abundant product ions at $\mathrm{m} / \mathrm{z}=137.02$ and/or 194.08 found in SORI 


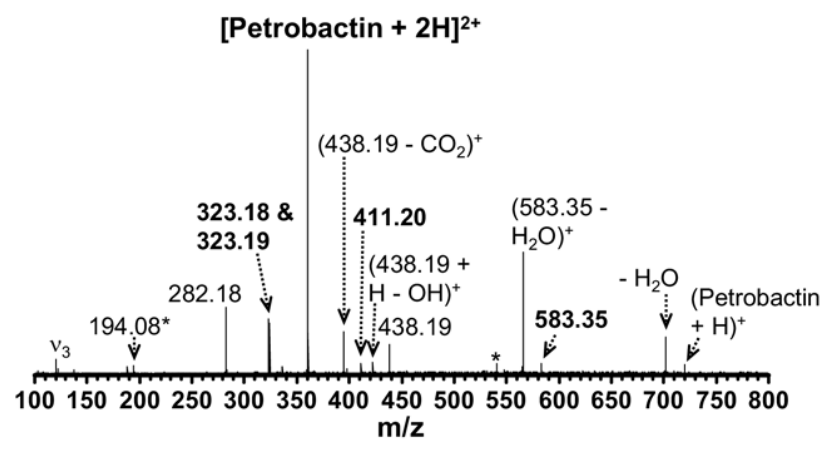

Figure 2. ECD spectrum from doubly protonated petrobactin (300 $\mathrm{ms},-1 \mathrm{~V}$ cathode bias voltage, 50 scans). Electronic noise and product ions present before electron irradiation (as a result of peptide vibrational excitation) are labeled with asterisks, $\nu_{3}=3$ rd harmonic.

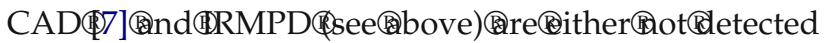
or of very low abundance, after ECD.

In addition, the product ion assigned as [583.35 $\left.\mathrm{H}_{2} \mathrm{O}\right]^{+}$, which constituted a minor product ion in SORI CAD and IRMPD, is the dominant product in ECD. (In all cases, control experiments were performed in which the hollow cathode was turned on but no electrons were pulsed. No $\mathrm{H}_{2} \mathrm{O}$ loss was observed in those experiments.) However, the product ion at $\mathrm{m} / \mathrm{z}=282.18$ is detected after ECD, SORI CAD, and IRMPD. ECD of [petrobactin $+2 \mathrm{H}]^{2+}$ generated four product ions at $\mathrm{m} / \mathrm{z}=583.35,323.18 / 324.19$, and 411.20 (see bold mass values in Scheme 2) that were not observed in SORI CAD or IRMPD of the same species. This complementary nature of ECD provides valuable additional structural information. As discussed above, the product ion at $m / z=583.35$ is structurally complementary to the one

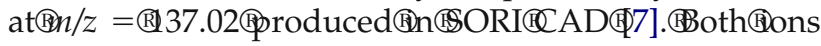
are formed from rupture of the terminal amide bond. Interestingly, formation of the three productions at $\mathrm{m} / \mathrm{z}=323.18 / 324.19$ and 411.20 is associated with rupture of two $\mathrm{C}-\mathrm{C}$ bonds (which are typically not cleaved in SORI CAD or IRMPD) close to the central carboxylate group. It has been shown that carboxylate groups constitute one of the primary Fe(III)-binding

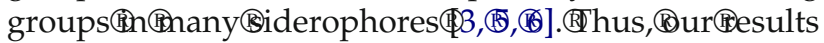
may indicate that ECD is better suited for characterizing such primary metal-binding groups. Moreover, these results illustrate that $\mathrm{ECD}$, compared to $\mathrm{CAD}$ and

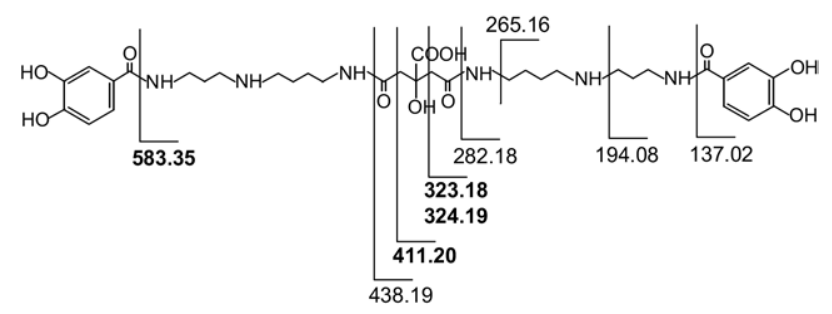

Scheme 2. Summary of bond cleavages observed in SORI CAD, IRMPD, and ECD of protonated petrobactin. Values in bold denote product ions that were detected only after ECD.
IRMPD, can provide complementary information on the structure of siderophores.

\section{MS/MS of Petrobactin Complexed with Divalent Metal Cations}

To evaluate the utility of ECD for characterization of metal-siderophore complexes and to explore their fragmentation patterns in ECD and SORI CAD, three divalent metal cations $\left(\mathrm{Ca}^{2+}, \mathrm{Fe}^{2+}\right.$, and $\left.\mathrm{Co}^{2+}\right)$ were selected for complexation with petrobactin. We recently established that divalent metal-containing peptide complexes display very different fragmentation behavior in

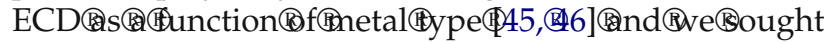
to establish whether a similar effect would be observed for petrobactin. For this purpose, ECD and SORI CAD spectra of petrobactin complexed with $\mathrm{Ca}^{2+}, \mathrm{Fe}^{2+}$, and $\mathrm{Co}^{2+}$, respectively, were acquired. Similar to the results for protonated petrobactin, these two fragmentation techniques resulted in very different fragmentation patterns. In ECD of [petrobactin $+\mathrm{M}]^{2+}\left(\mathrm{M}=\mathrm{Ca}^{2+}\right.$, $\mathrm{Fe}^{2+}$, (nd $\mathbb{C}^{2+} \mathrm{o}^{2+}$ ) the two former examples), the dominant product ion is the one assigned as $[581.33+\mathrm{M}]^{+}$, which corresponds to cleavage of one terminal amide bond of petrobactin. The numerical value used in the nomenclature for metal-containing product ions denotes the mass of a neutral fragment resulting from homolytic cleavage of a covalent bond. Similarly, the product ion at 583.35

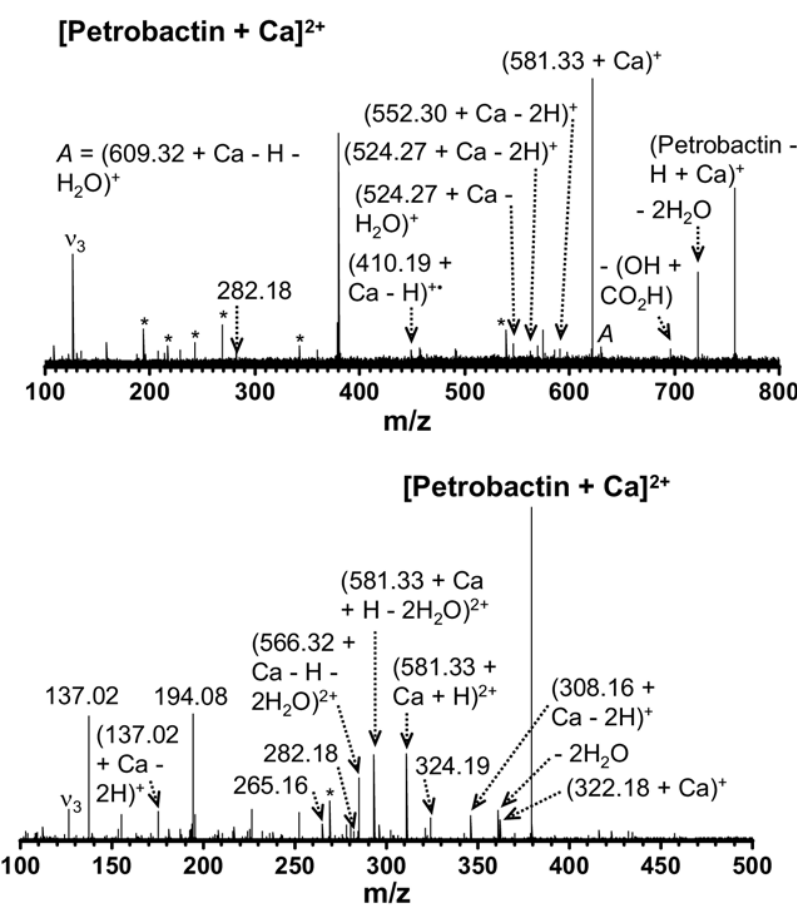

Figure 3. ECD (top, $300 \mathrm{~ms},-1 \mathrm{~V}$ cathode bias voltage, 32 scans) and SORI CAD (bottom, 14-ms argon pulse, 16 scans) spectra from $[\text { petrobactin }+\mathrm{Ca}]^{2+}$. Electronic noise and product ions present before electron irradiation (as a result of peptide vibrational excitation) are labeled with asterisks, $\nu_{3}=3$ rd harmonic. 

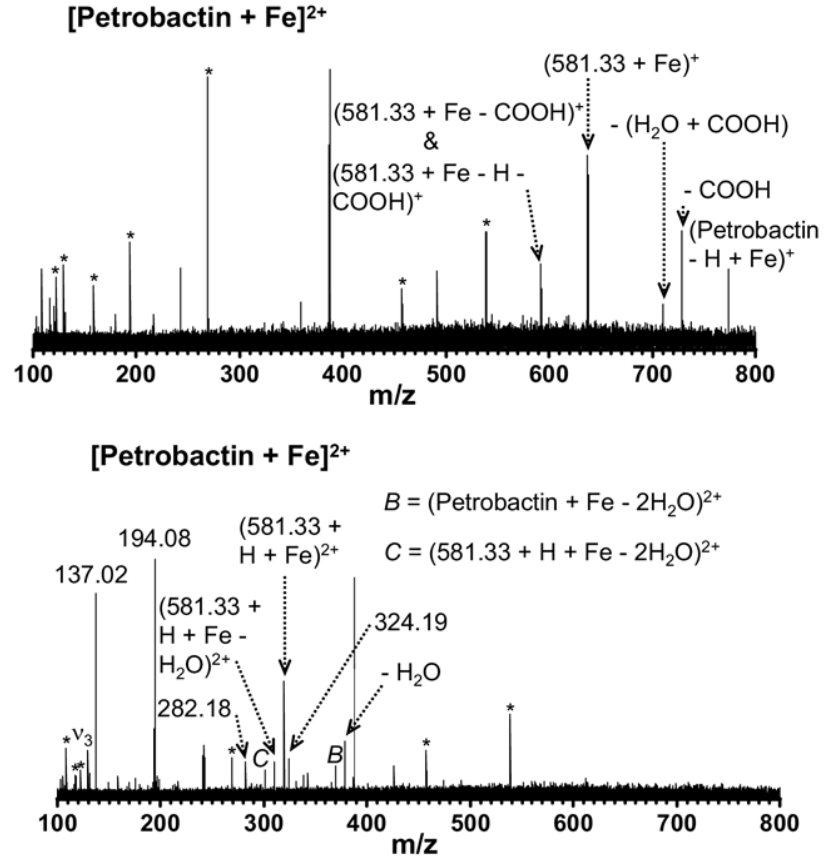

Figure 4. ECD (top, $300 \mathrm{~ms},-1 \mathrm{~V}$ cathode bias voltage, 32 scans) and SORI CAD (bottom, 14-ms argon pulse, 16 scans) spectra from $[\text { petrobactin }+\mathrm{Fe}]^{2+}$. Electronic noise and product ions present before electron irradiation (as a result of peptide vibrational excitation) are labeled with asterisks, $\nu_{3}=3$ rd harmonic.

observed in ECD of doubly protonated petrobactin (Scheme 2) corresponds to $[581.33+2 \mathrm{H}]^{+}$, that is, a singly protonated even-electron ion. By contrast, two singly charged non-metal-containing fragments at $\mathrm{m} / \mathrm{z}$ $=137.02$ and 194.08 constitute the most abundant product ions after SORI CAD of the same species

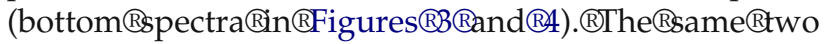
products were previously found to be dominant in SORI@AD®f other non-metal-containing product ions in the SORI CAD MS/MS spectra of [petrobactin $+\mathrm{M}]^{2+}$ : for example, products at $\mathrm{m} / \mathrm{z}=282.18$ and 324.19 are observed for all three divalent metal cations, whereas the product ion at $m / z=265.16$ is found for $\mathrm{Ca}^{2+}$ and $\mathrm{Co}^{2+}$. Interestingly, non-metal-containing product ions are virtually absent [a minor product at $\mathrm{m} / \mathrm{z}=282.18$ is

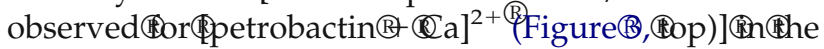
ECD spectra of [petrobactin $+\mathrm{M}]^{2+}\left(\mathrm{M}=\mathrm{Ca}^{2+}, \mathrm{Fe}^{2+}\right.$,

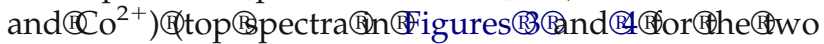
former examples). For $\mathrm{Fe}^{2+}$ and $\mathrm{Co}^{2+}$ (top spectrum in

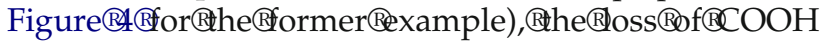
from $[581.33+\mathrm{M}]^{+}$and formation of [petrobactin $+\mathrm{Fe}$ $-\mathrm{H}]^{+}$are also major fragmentation pathways in ECD.

The product ion spectra obtained from ECD and SORI CAD of [petrobactin $+\mathrm{Ca}]^{2+}$ are more structurally informative than those involving $\mathrm{Fe}^{2+}$ and $\mathrm{Co}^{2+}$. Here three additional metal-containing product ions, assigned as $[410.19+\mathrm{Ca}-\mathrm{H}]^{+},[524.27+\mathrm{Ca}-2 \mathrm{H}]^{+}$, and $[552.30+\mathrm{Ca}-2 \mathrm{H}]^{+}$, are observed after ECD

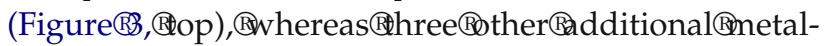

containing fragment ions, assigned as $[137.02+\mathrm{Ca}-$ $2 \mathrm{H}]^{+},[308.16+\mathrm{Ca}-2 \mathrm{H}]^{+}$, and $[322.18+\mathrm{Ca}]^{+}$are seen

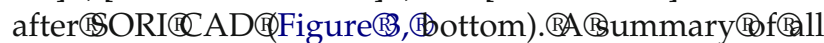
bond cleavages observed in ECD of divalent metaladducted species is shown in Scheme 3.

Bond cleavages resulting in products analogous to the ones assigned as $[137.02+\mathrm{Ca}-2 \mathrm{H}]^{+},[322.18+$ $\mathrm{Ca}]^{+}$, and $\left[410.19+\mathrm{Ca}-\mathrm{H}^{+\cdot}\right.$ were also observed in

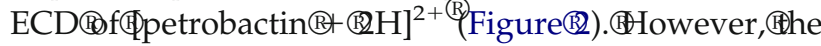
products assigned as $[308.16+\mathrm{Ca}-2 \mathrm{H}]^{+},[524.27+$ $\mathrm{Ca}-2 \mathrm{H}]^{+}$, and $[552.30+\mathrm{Ca}-2 \mathrm{H}]^{+}$are unique to the calcium data and correspond to cleavage of two C-C and one amine $\mathrm{N}-\mathrm{C}$ bond. In summary, all bond cleavages observed in MS/MS of protonated petrobactin were seen after ECD and/or SORI CAD of petrobactin complexed with divalent metal cations. Several additional product ions were detected after ECD of [petrobactin $+2 \mathrm{H}$ or $\mathrm{M}]^{2+}$ compared to the corresponding SORI CAD results. The fact that $[581.33+\mathrm{M}]^{+}(\mathrm{M}=$ $\mathrm{Ca}, \mathrm{Fe}, \mathrm{Co}$ ) is the most abundant $\mathrm{ECD}$ product ion for all three divalent metal complexes may indicate that the gas-phase structures of these complexes are similar.

\section{MS/MS of Petrobactin Complexed with Trivalent Metal Cations}

In biological environments, siderophores almost exclu-

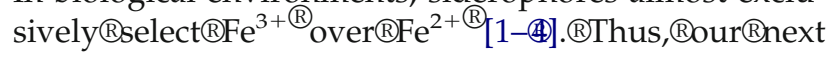
pursuit involved MS/MS characterization of petrobac-

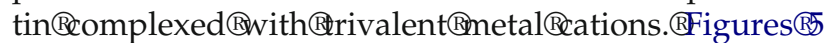
and@isplay petrobactin complexed with $\mathrm{Fe}^{3+}$ and $\mathrm{Ga}^{3+}$, respectively, with concomitant loss of one proton (presumably from the carboxylate group), that is, [petrobactin + $\mathrm{Fe} / \mathrm{Ga}-\mathrm{H}]^{2+}$. Similar to ECD of [petrobactin $\left.+\mathrm{Fe}\right]^{2+}$

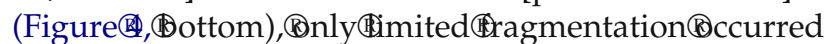
in $\mathrm{ECD}$ of [petrobactin $+\mathrm{Fe}-\mathrm{H}]^{2+}$ and [petrobactin + $\mathrm{Ga}-\mathrm{H}]^{2+}$. The most abundant product ion after ECD

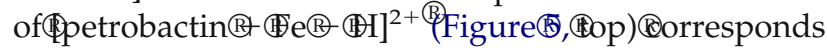
to loss of two water molecules from the $[581.33+\mathrm{Fe}]^{+}$ product. By contrast, a non-metal-containing product at $m / z=324.19$ is the most abundant fragment after ECD of [petrobactin $+\mathrm{Ga}-\mathrm{H}]^{2+}$. Another major difference between ECD of iron- and gallium-adducted petrobactin is that a charge-reduced precursor ion was detected for $\mathrm{Ga}^{3+}$ but not for $\mathrm{Fe}^{3+}$. This difference may be

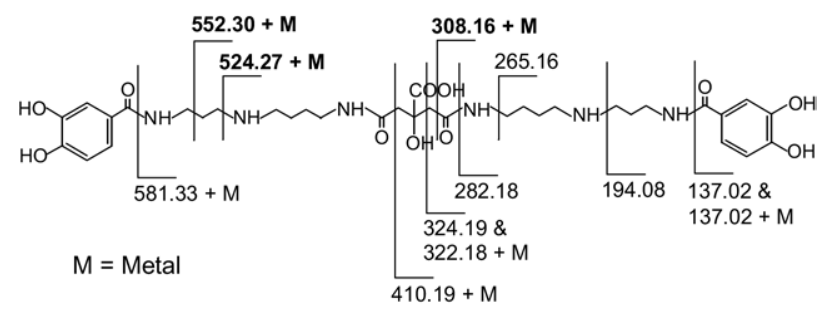

Scheme 3. Summary of bond cleavages observed in SORI CAD and ECD of metal-adducted petrobactin. Values in bold denote product ions that were not observed for protonated petrobactin. 

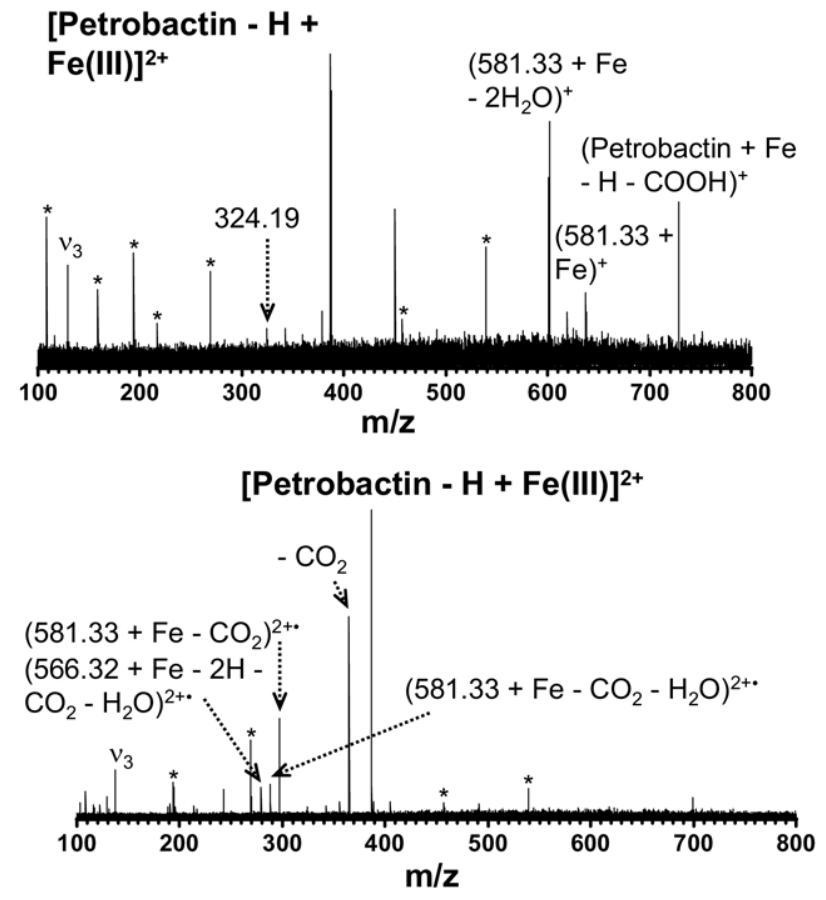

Figure 5. ECD (top, $300 \mathrm{~ms},-1 \mathrm{~V}$ cathode bias voltage, 32 scans) and SORI CAD (bottom, 8-ms argon pulse, 16 scans) spectra from [petrobactin $+\mathrm{Fe}-\mathrm{H}]^{2+}$. Electronic noise and product ions present before electron irradiation (as a result of peptide vibrational excitation) are labeled with asterisks, $\nu_{3}=3$ rd harmonic.

explained by the facile loss of $\mathrm{CO}_{2} / \mathrm{COOH}$ from the $\mathrm{Fe}^{3+}$ charge-reduced complex: abundant loss of $\mathrm{CO}_{2} /$ $\mathrm{COOH}$ was observed in both ECD and SORI CAD of

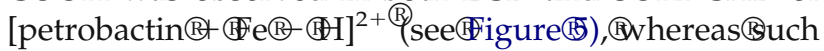
decarboxylation is very minor in ECD and SORI CAD of [petrobactin $+\mathrm{Ga}-\mathrm{H}]^{2+}$. The abundant loss of $\mathrm{CO}_{2} /$ $\mathrm{COOH}$ from the $\mathrm{Fe}^{3+}$ complex suggests that $\mathrm{Fe}^{3+}$ preferentially binds to the carboxylate groups of petrobactin whereas $\mathrm{Ga}^{3+}$ does not (consistent with literature proposing electron capture at metal centers and bond

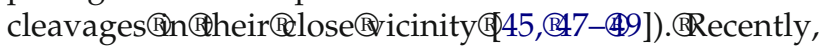

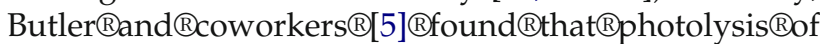
$\mathrm{Fe}^{3+}$-petrobactin complex resulted in decarboxylation and oxidation. They proposed a structure for $\mathrm{Fe}^{3+}$ petrobactin in which $\mathrm{Fe}^{3+}$ binds simultaneously to the carboxylate group and the hydroxyl groups of the dihydroxybenzoyl moiety. Our gas-phase results correlate with their proposed structure to some extent: the abundant loss of two $\mathrm{H}_{2} \mathrm{O}$ from $[581.33+\mathrm{Fe}]^{+}$indicates the presence of interactions between $\mathrm{Fe}^{3+}$ and hydroxyl groups. Similar preference for small neutral losses was reported by $\mathrm{O}^{\prime}$ Connor and coworkers in ECD of COvalently@yclic@tructuresథ50].

The SORI CAD MS/MS spectra of [petrobactin + $\mathrm{Fe}-\mathrm{H}]^{2+}$ and [petrobactin $\left.+\mathrm{Ga}-\mathrm{H}\right]^{2+}$ (bottom

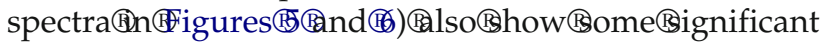
differences: although decarboxylation from the precursor ion or from metal-containing product ions is the dominant process in SORI CAD of [petrobactin $+\mathrm{Fe}-$ $\mathrm{H}]^{2+}$, dominant non-metal-containing product ions at $m / z=137.02,194.08,282.18$, and 324.19 were detected after SORI CAD of [petrobactin $+\mathrm{Ga}-\mathrm{H}]^{2+}$. The only metal-containing product ion found for $\mathrm{Ga}^{3+}$ is $[280.17+\mathrm{Ga}-\mathrm{H}]^{+}$. Another difference between the $\mathrm{Fe}^{3+}$ and $\mathrm{Ga}^{3+}$ petrobactin complexes is that all product ions observed in SORI CAD of [petrobactin $+\mathrm{Fe}-$ $\mathrm{H}^{2+}$ were doubly charged, whereas solely singly charged products, with the exception of the $\mathrm{H}_{2} \mathrm{O}$ loss peak, were observed in SORI CAD of [petrobactin $+\mathrm{Ga}-\mathrm{H}]^{2+}$. A possible explanation for the differences found in ECD and SORI CAD of [pectrobactin $+\mathrm{Fe}-\mathrm{H}]^{2+}$ and [pectrobactin $+\mathrm{Ga}-\mathrm{H}]^{2+}$ is that the latter species is zwitterionic with a mobile proton (i.e., with two deprotonated sites). Such a mobile proton would direct fragmentation in SORI CAD, resulting in abundant non-metal-containing product ions. In ECD, however, electrons can be captured either by this proton or by the

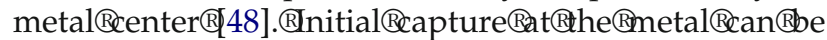
followed®by

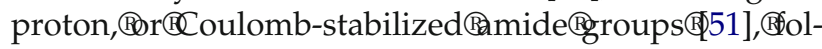

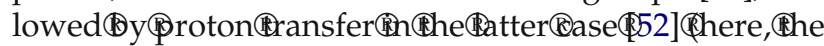
preferred source of the proton may be the mobile proton). These processes would result in formation of both metal-adducted and non-metal-containing product ions. Zwitterionic precursor structures were previously found to correlate with ECD fragmentation behavior@finetal-adducted@eptidesథ46,(153].

Intriguingly, the MS/MS results for the $\mathrm{Fe}^{3+}$ petrobactin complex are unique compared to the divalent metal ion complexes and to $\mathrm{Ga}^{3+}$. This observation is in agreement with the iron(III) specificity of sid-
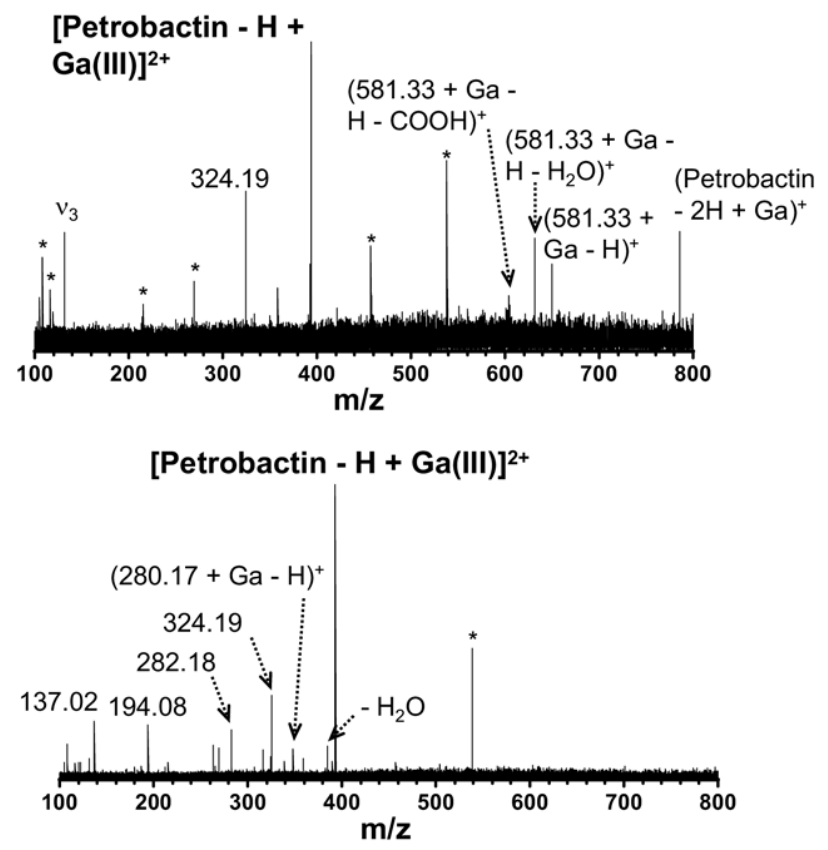

Figure 6. $\mathrm{ECD}$ (top, $300 \mathrm{~ms},-1 \mathrm{~V}$ cathode bias voltage, 32 scans) and SORI CAD (bottom, 8-ms argon pulse, 16 scans) spectra from [petrobactin $+\mathrm{Ga}-\mathrm{H}]^{2+}$. Electronic noise and product ions present before electron irradiation (as a result of peptide vibrational excitation) are labeled with asterisks, $\nu_{3}=3$ rd harmonic. 
erophores and may be explained by $\mathrm{Fe}^{3+}$ having a higher coordination number than that of other metals, thereby promoting stronger metal-ligand interactions. Consequently, formation of product ions containing $\mathrm{Fe}^{3+}$ would be energetically more favorable than formation of those without $\mathrm{Fe}^{3+}$.

\section{Conclusion}

We report that ECD provides complementary structural information about the siderophore petrobactin compared to SORI CAD and IRMPD, thereby presenting an advantage for mass spectrometric siderophore characterization. Our ECD and SORI CAD results are intriguing in that unique properties were found for $\mathrm{Fe}^{3+}$ petrobactin complexes, which are formed with superior selectivity compared to other metals. The significant differences observed in MS/MS of $\mathrm{Fe}^{3+}$-petrobactin complexes compared to other metal-petrobactin complexes may be ascribed to two possible reasons. First, metal-petrobactin complexes other than $\mathrm{Fe}^{3+}$-petrobactin may contain a mobile proton. The presence of this proton alters the fragmentation patterns in both ECD and SORI CAD. Second, because metal-ligand interactions for $\mathrm{Fe}^{3+}$ are much stronger than those of other metal cations, formation of $\mathrm{Fe}^{3+}$-containing product ions is energetically favorable, particularly in SORI CAD. For other metal cations, however, formation of non-metal-containing products is also favored. Application of ECD to other types of siderophores is under way.

\section{Acknowledgments}

This work was supported by the Searle Scholars Program, Dow Corning Corporation, Eli Lilly and Company, the University of Michigan, and grants RP1 and DP18 from the NIH Great Lakes Center of Excellence for Biodefense and Emerging Infectious Diseases Research.

\section{References}

1. Boukhalfa, H.; Crumbliss, A. L. Chemical Aspects of Siderophore Mediated Iron Transport. Biometals 2002, 15, 325-339.

2. Faraldo-Gomez, J. D.; Sansom, M. S. P. Acquisition of Siderophores in Gram-Negative Bacteria. Nat. Rev. Mol. Cell. Biol. 2003, 4, 105-116.

3. Neilands, J. B. Siderophores: Structure and Function of Microbial Iron Transport Compounds. J. Biol. Chem. 1995, 270, 26723-26726.

4. Renshaw, J. C.; Robson, G. D.; Trinci, A. P. J.; Wiebe, M. G.; Livens, F. R.; Collison, D.; Taylor, R. J. Fungal Siderophores: Structures, Functions and Applications. Mycol. Res. 2002, 106, 1123-1142.

5. Barbeau, K.; Zhang, G. P.; Live, D. H.; Butler, A. Petrobactin, a Photoreactive Siderophore Produced by the Oil-Degrading Marine Bacterium Marinobacter hydrocarbonoclasticus. J. Am. Chem. Soc. 2002, 124, 378-379.

6. Koppisch, A. T.; Browder, C. C.; Moe, A. L.; Shelley, J. T.; Kinke, B. A.; Hersman, L. E.; Iyer, S.; Ruggiero, C. E. Petrobactin is the Primary Siderophore Synthesized by Bacillus anthracis str. Sterne under Conditions of Iron Starvation. Biometals 2005, 18, 577-585.

7. Lee, J. Y.; Janes, B. K.; Passalacqua, K. D.; Pfleger, B.; Bergman, N. H.; Liu, H.; Hakansson, K.; Somu, R. V.; Aldrich, C. C.; Cendrowski, S.; Hanna, P.; Sherman, D. H. Biosynthetic Analysis of the Petrobactin Siderophore Pathway from Bacillus anthracis. J. Bacteriol. (December 22, 2006). doi:10.1128/JB.01526-06.

8. Barbeau, K.; Rue, E. L.; Butler, A. Photochemical Cycling of Iron in the Surface Ocean Mediated by Microbial Iron(III)-Binding Ligands. Nature 2001, 413, 409-413.

9. Gledhill, M. Electrospray Ionisation Mass Spectrometry of Hydroxamate Siderophores. Analyst 2001, 126, 1359-1362.
10. Gledhill, M.; McCormack, P.; Ussher, S.; Achterberg, E. P.; Mantoura, R. F. C.; Worsfold, P. J. Production of Siderophore Type Chelates by Mixed Bacterioplankton Populations in Nutrient Enriched Seawater Incubations. Marine Chem. 2004, 88, 75-83.

11. Gobin, J.; Moore, C. H.; Reeve, J. R.; Wong, D. K.; Gibson, B. W. Horwitz, M. A. Iron Acquisition by Mycobacterium tuberculosis-Isolation and Characterization of a Family of Iron-Binding Exochelins. Proc. Natl. Acad. Sci. U.S.A. 1995, 92, 5189-5193.

12. Groenewold, G. S.; Van Stipdonk, M. J.; Gresham, G. L.; Chien, W.; Bulleigh, K.; Howard, A. Collision-Induced Dissociation Tandem Mass Spectrometry of Desferrioxamine Siderophore Complexes from Electrospray Ionization of $\mathrm{UO}_{2}^{2+}, \mathrm{Fe}^{3+}$ and $\mathrm{Ca}^{2+}$ Solutions. J. Mass Spectrom. 2004, 39, 752-761.

13. Hayen, H.; Volmer, D. A. Rapid Identification of Siderophores by Combined Thin-Layer Chromatography/Matrix-assisted Laser Desorption/ Ionization Mass Spectrometry. Rapid Commun. Mass Spectrom. 2005, 19, 711-720.

14. Kaltashov, I. A.; Cotter, R. J.; Feinstone, W. H.; Woods, A. S. Ferrichrome: Surprising Stability of a Cyclic Peptide-Fe ${ }^{\mathrm{II}}$ Complex Revealed by Mass Spectrometry. J. Am. Soc. Mass Spectrom. 1997, 8, 1070-1077.

15. Kilz, S.; Lenz, C.; Fuchs, R.; Budzikiewicz, H. A Fast Screening Method for the Identification of Siderophores from Fluorescent Pseudomonas spp. by Liquid Chromatography Electrospray Mass Spectrometry. J. Mass Spectrom. 1999, 34, 281-290.

16. Lane, S. J.; Marshall, P. S.; Upton, R. J.; Ratledge, C.; Ewing, M. Novel Extracellular Mycobactins, the Carboxymycobactin from Mycobacterium avium. Tetrahedron Lett. 1995, 36, 4129-4132.

17. Martinez, J. S.; Carter-Franklin, J. N.; Mann, E. L.; Martin, J. D. Haygood, M. G.; Butler, A. Structure and Membrane Affinity of a Suite of Amphiphilic Siderophores Produced by a Marine Bacterium. Proc. Natl. Acad. Sci. U.S.A. 2003, 100, 3754-3759.

18. Martinez, J. S.; Zhang, G. P.; Holt, P. D.; Jung, J.-T.; Carrano, C. J. Haygood, M. G.; Butler, A. Self-Assembling Amphiphilic Siderophores from Marine Bacteria. Science 2000, 287, 1245-1247.

19. McCormack, P.; Worsfold, P. J.; Gledhill, M. Separation and Detection of Siderophores Produced by Marine Bacterioplankton using High Performance Liquid Chromatography with Electrospray Ionization Mass Spectrometry. Anal. Chem. 2003, 75, 2647-2652.

20. Spasojević, I.; Boukhalfa, H.; Stevens, R. D.; Crumbliss, A. L. Aqueous Solution Speciation of $\mathrm{Fe}$ (III) Complexes with Dihydroxamate Siderophores Alcaligin and Rhodotorulic Acid and Synthetic Analogues Using Electrospray Ionization Mass Spectrometry. Inorg. Chem. 2001, 40, 49-58.

21. Wong, D. K.; Gobin, J.; Horwitz, M. A.; Gibson, B. W. Characterization of Exochelins of Mycobacterium avium: Evidence for Saturated and Unsaturated and for Acid and Ester Forms. J. Bacteriol. 1996, 178 6394-6398.

22. Zou, G. Z.; Boyer, G. L. Synthesis and Properties of Different Metal Complexes of the Siderophore Desferriferricrocin. Biometals 2005, 18, 63-74.

23. Khalil-Rizvi, S.; Toth, S. I.; van der Helm, D.; Vidavsky, I.; Gross, M. L. Structures and Characteristics of Novel Siderophores from Plant Deleterious Pseudomonas fluorescens A225 and Pseudomonas putida ATCC 39167. Biochemistry 1997, 36, 4163-4171.

24. Cooper, H. J.; Hakansson, K.; Marshall, A. G. The Role of Electron Capture Dissociation in Biomolecular Analysis. Mass Spectrom. Rev. 2005, 24, 201-222.

25. McLafferty, F. W.; Horn, D. M.; Breuker, K.; Ge, Y.; Lewis, M. A.; Cerda, B.; Zubarev, R. A.; Carpenter, B. K. Electron Capture Dissociation of Gaseous Multiply Charged Ions by Fourier Transform Ion Cyclotron Resonance. J. Am. Soc. Mass Spectrom. 2001, 12, 245-249.

26. Zubarev, R. A. Electron Capture Dissociation Tandem Mass Spectrometry. Curr. Opin. Biotechnol. 2004, 15, 12-16.

27. Adamson, J. T.; Hakansson, K. Infrared Multiphoton Dissociation and Electron Capture Dissociation of High-Mannose Type Glycopeptides. J. Proteome Res. 2006, 5, 493-501.

28. Hakansson, K.; Cooper, H. J.; Emmett, M. R.; Costello, C. E.; Marshall, A. G.; Nilsson, C. L. Electron Capture Dissociation and Infrared Multiphoton Dissociation MS/MS of an N-glycosylated Tryptic Peptide Yield Complementary Sequence Information. Anal. Chem. 2001, 73, 4530-4536.

29. Mirgorodskaya, E.; Roepstorff, P.; Zubarev, R. A. Localization of O-glycosylation Sites in Peptides by Electron Capture Dissociation in a Fourier Transform Mass Spectrometer. Anal. Chem. 1999, 71, 4431-4436.

30. Stensballe, A.; Norregaard-Jensen, O.; Olsen, J. V.; Haselmann, K. F.; Zubarev, R. A. Electron Capture Dissociation of Singly and Multiply Phosphorylated Peptides. Rapid Commun. Mass Spectrom. 2000, 14, 1793-1800.

31. Breuker, K.; Oh, H.; Horn, D. M.; Cerda, B. A.; McLafferty, F. W. Detailed Unfolding and Folding of Gaseous Ubiquitin Ions Characterized by Electron Capture Dissociation. J. Am. Chem. Soc. 2002, 124, 6407-6420.

32. Horn, D. M.; Breuker, K.; Frank, A. J.; McLafferty, F. W. Kinetic Intermediates in the Folding of Gaseous Protein Ions Characterized by Electron Capture Dissociation Mass Spectrometry. J. Am. Chem. Soc. 2001, 123, 9792-9799.

33. Robinson, E. W; Leib, R. D. Williams, E. R. The Role of Conformation on Electron Capture Dissociation of Ubiquitin. J. Am. Soc. Mass Spectrom. 2006, 17, 1469-1479.

34. Cerda, B. A.; Horn, D. M.; Breuker, K.; McLafferty, F. W. Sequencing of Specific Copolymer Oligomers by Electron-Capture-Dissociation Mass Spectrometry. J. Am. Chem. Soc. 2002, 124, 9287-9291. 
35. Koster, S.; Duursma, M. C.; Boon, J. J.; Heeren, R. M. A.; Ingemann, S.; van Benthem, R. A. T. M. de Koster, C. G. Electron Capture and Collisionally Activated Dissociation Mass Spectrometry of Doubly Charged Hyperbranched Polyesteramides. J. Am. Soc. Mass Spectrom. 2003, 14, 332-341.

36. Hakansson, K.; Hudgins, R. R.; Marshall, A. G.; O'Hair, R. A. J. Electron Capture Dissociation and Infrared Multiphoton Dissociation of Oligodeoxynucleotide Dications. J. Am. Soc. Mass Spectrom. 2003, 14, $23-41$.

37. Schultz, K. N.; Hakansson, K. Rapid Electron Capture Dissociation of Mass-Selectively Accumulated Oligodeoxynucleotide Dications. Int. J. Mass Spectrom. 2004, 234, 123-130.

38. Yang, J.; Hakansson, K. Fragmentation of Oligoribonucleotides from Gas-phase Ion-Electron Reactions. J. Am. Soc. Mass Spectrom. 2006, 17, 1369-1375.

39. Kleinnijenhuis, A. J.; Duursma, M. C.; Breukink, E.; Heeren, R. M. A.; Heck, A. J. R. Localization of Intramolecular Monosulfide Bridges in Lantibiotics Determined with Electron Capture Dissociation. Anal. Chem. 2003, 75, 3219-3225.

40. Cendrowski, S.; MacArthur, W.; Hanna, P. Bacillus anthracis Requires Siderophore Biosynthesis for Growth in Macrophages and Mouse Virulence. Mol. Microbiol. 2004, 51, 407-417.

41. de Koning L. J * Nibbering N. M. M. van Orden, S. L. Laukien, F. H. Mass Selection of Ions in a Fourier Transform Ion Cyclotron Resonance Trap Using Correlated Harmonic Excitation Fields (CHEF). Int. J. Mass Spectrom. 1997, 165, 209-219.

42. Tsybin, Y. O.; Witt, M.; Baykut, G.; Kjeldsen, F.; Hakansson, P. Combined Infrared Multiphoton Dissociation and Electron Capture Dissociation with a Hollow Electron Beam in Fourier Transform Ion Cyclotron Resonance Mass Spectrometry. Rapid Commun. Mass Spectrom. 2003, 17, 1759-1768

43. Senko, M. W.; Canterbury, J. D.; Guan, S.; Marshall, A. G. A HighPerformance Modular Data System for FT-ICR Mass Spectrometry. Rapid Commun. Mass Spectrom. 1996, 10, 1839-1844.
44. Wysocki, V. H.; Tsaprailis, G.; Smith, L. L.; Breci, L. A. Special Feature: Commentary-Mobile and Localized Protons: A Framework for Understanding Peptide Dissociation. J. Mass Spectrom. 2000, 35, 1399-1406.

45. Liu, H.; Hakansson, K. Divalent Metal-Peptide Interactions Probed by Electron Capture Dissociation of Trications. J. Am. Soc. Mass Spectrom. 2006, 17, 1731-1741.

46. Liu, H.; Hakansson, K. Electron Capture Dissociation of Tyrosine O-Sulfated Peptides Complexed with Divalent Metal Cations. Anal. Chem. 2006, 78, 7570-7576.

47. Kellersberger, K. A.; Fabris, D. Top-Down Investigation of Meta Coordination in Metalloproteins by ESI-FTMS and Electron Capture Dissociation. Proceedings of the 52nd ASMS Conference on Mass Spectrometry and Allied Topics, Nashville, TN, May 23-27, 2004; CD-ROM

48. Kleinnijenhuis, A. J.; Mihalca, R.; Heeren, R. M. A.; Heck, A. J. R. Atypical Behavior in the Electron Capture Induced Dissociation of Biologically Relevant Transition Metal Ion Complexes of the Peptide Hormone Oxytocin. Int. J. Mass Spectrom. 2006, 253, 217-224.

49. Zubarev, R. A.; Haselmann, K. F.; Budnik, B.; Kjeldsen, F.; Jensen, F. Towards an Understanding of the Mechanism of Electron Capture Dissociation: A Historical Perspective and Modern Ideas. Eur. Mass Spectrom. 2002, 8, 337-349.

50. Leymarie, N.; Costello, C. E.; O'Connor, P. B. Electron Capture Dissociation Initiates a Free Radical Reaction Cascade. J. Am. Chem. Soc. 2003, 125, 8949-8958.

51. Sobczyk, M.; Anusiewicz, W.; Berdys-Kochanska, J.; Sawicka, A.; Skurski, P.; Simons, J. Coulomb-assisted Dissociative Electron Attachment: Application to a Model Peptide. J. Phys. Chem. A 2005, 109, $250-258$.

52. Syrstad, E. A.; Turecek, F. Toward a General Mechanism of Electron Capture Dissociation. J. Am. Soc. Mass Spectrom. 2005, 16, 208-224.

53. Fung, Y. M. E.; Liu, H.; Chan, T. W. D. Electron Capture Dissociation of Peptides Metalated with Alkaline-Earth Metal Ions. J. Am. Soc. Mass Spectrom. 2006, 17, 757-771. 